\title{
Chemotherapy sensitivity testing on ovarian cancer cells isolated from malignant ascites
}

\author{
Judith E. den Ouden ${ }^{1}$, Guido J.R. Zaman ${ }^{2}$, Jelle Dylus ${ }^{2}$, Antoon M. van Doornmalen², \\ Winfried R. Mulder ${ }^{2}$, Yvonne Grobben ${ }^{2}$, Wilhelmina E. van Riel ${ }^{2}$, Joanne A. de \\ Hullu$^{1}$, Rogier C. Buijsman ${ }^{2}$ and Anne M. van Altena ${ }^{1}$ \\ ${ }^{1}$ Radboud Institute for Health Sciences, Radboud University Medical Center, Obstetrics and Gynecology, Nijmegen, The \\ Netherlands \\ ${ }^{2}$ Netherlands Translational Research Center B.V., Oss, The Netherlands \\ Correspondence to: Anne M. van Altena, email: Anne.vanAltena@radboudumc.nl
}

Keywords: ovarian cancer; chemotherapy sensitivity; prediction; ascites; proliferation assays

Received: April 08, $2020 \quad$ Accepted: November 12, $2020 \quad$ Published: December 08, 2020

Copyright: (๑) 2020 den Ouden et al. This is an open access article distributed under the terms of the Creative Commons Attribution License (CC BY 3.0), which permits unrestricted use, distribution, and reproduction in any medium, provided the original author and source are credited.

\section{ABSTRACT}

Background: In epithelial ovarian cancer (EOC), 15-20\% of the tumors do not respond to first-line chemotherapy (paclitaxel with platinum-based therapy), and in recurrences this number increases. Our aim is to determine the feasibility of cell proliferation assays of tumor cells isolated from malignant ascites to predict in vitro chemotherapy sensitivity, and to correlate these results with clinical outcome.

Materials and Methods: Ascites was collected from twenty women with advanced EOC. Cell samples were enriched for tumor cells and EOC origin was confirmed by intracellular staining of CK7, surface staining of CA125 and EPCAM, and HE4 gene expression. In vitro sensitivity to chemotherapy was determined in cell proliferation assays using intracellular ATP content as an indirect measure of cell number. In vitro drug response was quantified by calculation of the drug concentration at which cell growth was inhibited with $\mathbf{5 0 \%}$. Clinical outcome was determined using posttreatment CA125 level.

Results: Cell samples of twenty patients were collected, of which three samples that failed to proliferate were excluded in the analysis $(15 \%)$. Three other samples were excluded, because clinical outcome could not be determined correctly. In twelve of the fourteen remaining cases $(86 \%)$ in vitro drug sensitivity and clinical outcome corresponded, while in two samples $(14 \%)$ there was no correspondence.

Conclusions: Our study demonstrates the feasibility of drug sensitivity tests using tumor cells isolated from ascites of advanced EOC patients. Larger observational studies are required to confirm the correlation between the in vitro sensitivity and clinical outcome.

\section{INTRODUCTION}

Epithelial ovarian cancer (EOC) is the most lethal gynecologic malignancy worldwide [1]. Most EOC patients $(70 \%)$ are diagnosed in an advanced stage, i.e., International Federation of Gynecology and Obstetrics (FIGO) stage IIb - IV. The prognosis of advanced stage EOC is poor, with a 5-year survival rate of $20-30 \%$ [1-3].

Standard first-line treatment for advanced EOC consists of a combination of a debulking surgery and chemotherapy, with paclitaxel and a platinum-based compound administered either intravenously (IV) or intraperitoneally (IP) [4]. Despite extensive treatment, the prognosis of ovarian cancer has only slightly improved over the last three decades. In approximately $15-20 \%$ of women with EOC the tumor does not respond to first-line chemotherapy, and in recurrences this number increases due to drug resistance [5]. Although differences in therapy response have been reported between different histological subtypes [6], histology is not taken into account when therapy is selected. However, ovarian cancers with $B R C A$ germline and somatic mutations are more sensitive to 
platinum-based therapy and Poly (ADP ribose) polymerase 1 (PARP)-inhibitors, and have better overall survival $[7,8]$. Approximately $10-20 \%$ of EOC tumors harbor germline mutations in either BRCA1 or BRCA2 [9, 10]. About $60-70 \%$ of the $B R C A$ positive tumor tests are based on a germline mutation, the others are somatic mutations [10]. BRCA gene mutation status is a patient stratification marker for PARP inhibitors, but not for first line platinumbased chemotherapy [7-10].

There is a need of more tools and assays to predict the clinical response to chemotherapy in EOC patients [3]. Ideally, this would avoid suboptimal treatment and prevent delay of optimal treatment, and thus clinical deterioration, unnecessary side effects of inadequate chemotherapeutics, and high societal costs.

EOC patients often present with high volumes of malignant ascites, which is easily accessible, and is routinely collected for diagnostic purposes or relief of complaints. Ascites is potentially an excellent source for biomarker discovery [11]. Konecny and co-workers reported a significant decrease in progression-free and overall survival (PFS, OS) of patients tested to be resistant in vitro using ATP tumor chemosensitivity assays performed on tumor cells isolated from biopsies [12]. Other studies describe the use of biomarkers in ascites to predict responses to initial therapy [13-15], although there are currently no biomarkers that have been validated. Furthermore, there are no studies that describe the use of in vitro cell proliferation assays to predict response to primary treatment.

A more personalized, tumor-specific treatment for EOC patients would be of great value to improve therapeutic decision-making and clinical outcome. The aim of this study is to determine whether tumor cells isolated from ascites of EOC patients can be used to determine chemotherapy sensitivity by using in vitro proliferation assays.

\section{RESULTS}

We identified twenty patients diagnosed with EOC and presenting with ascites, who gave consent for the study. Three patient samples (ps.) (15\%) were excluded, because cells isolated from the ascites did not proliferate in vitro. The clinical outcome of three other patients could not be determined correctly. One patient stopped primary treatment because she refused a relaparotomy for an anastomotic leakage after interval debulking surgery. The second patient did not have an elevated level of cancer antigen 125 (CA125) in serum at time of diagnosis. The third patient switched after interval debulking surgery to liposomal doxorubicin (Caelyx) plus carboplatin. These three patients were also excluded. Of the remaining fourteen patients included in the study, the median age at diagnosis of the patients was 62 years (range 50-71 years). The Karnofsky score at time of diagnosis for patients was between 70 and 90. See Table 1 for an overview of the clinicopathological data, and Figure 1 for an overview of in- and exclusions. All patients received carboplatin or cisplatin, and paclitaxel as a first-line intravenous (IV), or intraperitoneal (IP) chemotherapy treatment. Three patients received IP cisplatin, of which two finished the six cycles (ps. 1 and 6). One patient (ps. 3) also received IV carboplatin because IP-chemotherapy was stopped after one cycle.

Ascites is known to contain a mixture of cells, including tumor cells, immune cells, cancer-associated fibroblasts and mesothelial cells [16, 17]. The majority of cells in the unprocessed ascites are immune cells, as determined by CD45-positive staining in flow cytometry experiments. The bulk of the immune cells were removed by overnight adherence of the cells to tissue-culture flasks, during which the bulk of immune cells remains in suspension. After culturing the adhering cells for two to three weeks, expression of the ovarian cancer markers CA125 and HE4 was determined by qPCR (Figure 2). Expression levels differed among the samples, but all samples expressed at least one of the two ovarian cancer marker genes. Flow cytometry analysis of five samples (ps. 1, 2, 4, 12 and 14) further confirmed the tumor origin by cell surface staining of the ovarian cancer marker CA125 and the epithelial cell marker epithelial cell adhesion molecule (EpCAM), and intracellular staining of cytokeratin 7 (CK7) (Figure 3). Expression levels were quantified by determination of the ratio of the median fluorescence intensity (MFI) after staining with the specific antibodies relative to staining with isotype control antibody (Table 3). Moreover, the percentage of cells stained positive for the different markers was determined. All samples stained positive for CA125 and CK7. Ps. 12 and ps. 14 also stained positive for EpCAM (Figure 3 and Table 3). The percentage of CA125-positive cells ranged from 42 to $90 \%$ and CK7-positive from 80 to $93 \%$ (Table 3). Marker expression thus confirmed the EOC origin of the adherent cell fractions. In addition, cells were rather uniform in morphology (Figure 4).

To determine the sensitivity of the adherent cell cultures to chemotherapy, cell proliferation assays were performed with serial dilutions of the clinical agents (Figure 5 and Supplementary Figure 1). The effect of the chemotherapy on cell growth was quantified by calculation of the drug concentration that resulted in $50 \%$ inhibition of cell growth $\left(\mathrm{GI}_{50}\right)$ in comparison to cells treated with vehicle. Clinical data of each patient and results of the proliferation assays are summarized in Table 2. $\mathrm{GI}_{50}$ of carboplatin, cisplatin, and paclitaxel were separately correlated with the CA125 level in serum after primary treatment. No significant correlation between CA125 levels and drug sensitivity was observed; carboplatin (Pearson 0.311, $P=0.324$ ), cisplatin (Pearson $-0.762, P=0.449$ ), and paclitaxel (Pearson 0.333, $P=$ $0.245)$. We then studied the variables classified in groups. 


\begin{tabular}{|c|c|}
\hline & Frequency $(n=14)$ \\
\hline Median age in years & 62 (range 50-71) \\
\hline $\begin{array}{l}\text { Primary origin of tumor } \\
\text { Ovarian } \\
\text { Fallopian tubes } \\
\text { Adnexal } \\
\text { Primary peritoneal } \\
\text { Unknown }\end{array}$ & $\begin{array}{l}4 \\
2 \\
6 \\
1 \\
1\end{array}$ \\
\hline $\begin{array}{l}\text { Karnofsky performance status } \\
\begin{array}{l}70 \\
80 \\
90 \\
\text { Unknown }\end{array}\end{array}$ & $\begin{array}{l}2 \\
5 \\
6 \\
1\end{array}$ \\
\hline $\begin{array}{l}\text { Treatment } \\
\text { Primary debulking } \\
\text { Interval debulking } \\
\text { Only chemotherapy }\end{array}$ & $\begin{array}{l}7 \\
6 \\
1\end{array}$ \\
\hline $\begin{array}{l}\text { Type of chemotherapy treatment } \\
\text { Carboplatin }+ \text { paclitaxel } \\
\text { Cisplatin }+ \text { paclitaxel } \\
\text { Both carbo- and cisplatin }+ \text { paclitaxel }\end{array}$ & $\begin{array}{c}11 \\
2 \\
1\end{array}$ \\
\hline
\end{tabular}

The median $\mathrm{GI}_{50}$ was $79.3 \mu \mathrm{mol} / \mathrm{L}$ for carboplatin, 11.8 $\mu \mathrm{mol} / \mathrm{L}$ for cisplatin and $29.5 \mathrm{nmol} / \mathrm{L}$ for paclitaxel. A $\mathrm{GI}_{50}$ of carboplatin, cisplatin, and paclitaxel equal to or less their respective median $\mathrm{GI}_{50}$ was considered as a 'good' in vitro response, while $\mathrm{GI}_{50}$ values greater than the respective median $\mathrm{GI}_{50}$ values was considered as a 'poor' in vitro response (Table 2). Three patients (ps. 1, 3, and 6) received IP cisplatin, and they all showed a good clinical response. Therefore, only one group of the ordinal variables is available and statistical analyses could not be performed. No significant difference between clinical outcome of CA125 level and $\mathrm{GI}_{50}$ of carboplatin $(P=$ $0.268)$, or paclitaxel $(P=0.219)$ could be identified. Also, no significant difference in platinum sensitivity and $\mathrm{GI}_{50}$ of carboplatin or paclitaxel was found (both $P=1.000$ ), and no difference between $B R C A 1$ or $B R C A 2$ mutated samples and the compounds was seen $(P=0.213$ for carboplatin, and $P=0.681$ for paclitaxel).

In clinical practice, carboplatin and paclitaxel are given in combination therapy. However, testing of the two agents in mixtures did not increase the response in vitro (Supplementary Figure 2 and Supplementary Table 1). In contrast, if the in vitro response data to the single agents are combined per case, twelve patients $(86 \%)$ showed correlation between clinical outcome and the results of the in vitro assays. Thus, good clinical outcome correlated with a good response to at least one of the compounds in the in vitro assays, and poor clinical outcome correlated to poor in vitro response to both compounds. As an example, a poor clinical outcome was seen in ps. 7 (Table 2). After six cycles of chemotherapy treatment, the CA125 level in serum was still elevated $(258 \mathrm{E} / \mathrm{mL})$. The patient did not undergo surgery because of the poor biochemical response after neoadjuvant chemotherapy (NACT) and a computed tomography (CT)-scan that still showed considerable tumor mass. The in vitro response of the corresponding ascites cell sample was in line with a poor outcome, that is, the $\mathrm{GI}_{50}$ was high for both carboplatin $(100 \mu \mathrm{mol} / \mathrm{L})$ and paclitaxel (66 nmol/L) (Table 2 and Figure 5). Another case in which clinical outcome was predicted well is that of ps. 12. The in vitro tests predicted a good clinical outcome (Figure 5), which was confirmed by the low CA125 level of $14 \mathrm{E} / \mathrm{mL}$ after primary treatment (Table 2). Only two samples (14\%; ps. 10 and 13) did not show any correlation (Table 2). Both patients had a good clinical outcome with post-treatment CA125 levels of $15 \mathrm{E} / \mathrm{mL}$ and $8 \mathrm{E} / \mathrm{mL}$, respectively, while the in vitro response was poor for both compounds. Both had a $\mathrm{GI}_{50}$ of $100 \mu \mathrm{mol} / \mathrm{L}$ for carboplatin and, respectively, a $\mathrm{GI}_{50}$ of $35 \mathrm{nmol} / \mathrm{L}$ and $79 \mathrm{nmol} / \mathrm{L}$ for paclitaxel.

\section{DISCUSSION}

In this study, we determined the in vitro sensitivity of tumor cells isolated from ascites to firstline chemotherapeutic agents. The results were related to the clinical response of EOC patients to primary treatment. $85 \%$ of the samples had a sufficient number of proliferating tumor cells to determine the effect of chemotherapy treatment on cell viability and proliferation. There was no significant difference in sensitivity between the $\mathrm{GI}_{50}$ of carboplatin or paclitaxel and clinical outcome. However, when the in vitro response to both single agents was considered, twelve patient samples $(86 \%)$ showed a 
similar response in in vitro drug sensitivity and clinical outcome. In two samples (14\%) no correlation was observed.

Although we used a small group of patient samples, this study demonstrates the feasibility of predicting chemotherapy sensitivity by combining the in vitro response to the agents, carboplatin, cisplatin and paclitaxel on proliferation of cells isolated from malignant ascites. The use of cells isolated from ascites has a major advantage over the use of surgical biopsies [11, 12], because it is minimal invasive and allows drug sensitivity testing prior to the start of primary chemotherapy treatment. Furthermore, in vitro proliferation assays in $2 \mathrm{D}$ cell cultures have a major advantage over proliferation assays in 3D or organoid cultures [18], which take much longer and are technically more challenging. In clinical practice, performing in vitro testing in ascites prevents exposure of patients that will not respond to toxic chemotherapeutics.

Two samples did not show any correlation. These patients (ps. 10 and 13) had a good clinical outcome, while the cells isolated from ascites of these patient showed low in vitro drug sensitivity. Study of the clinical record of one of these patients revealed that the start of adjuvant

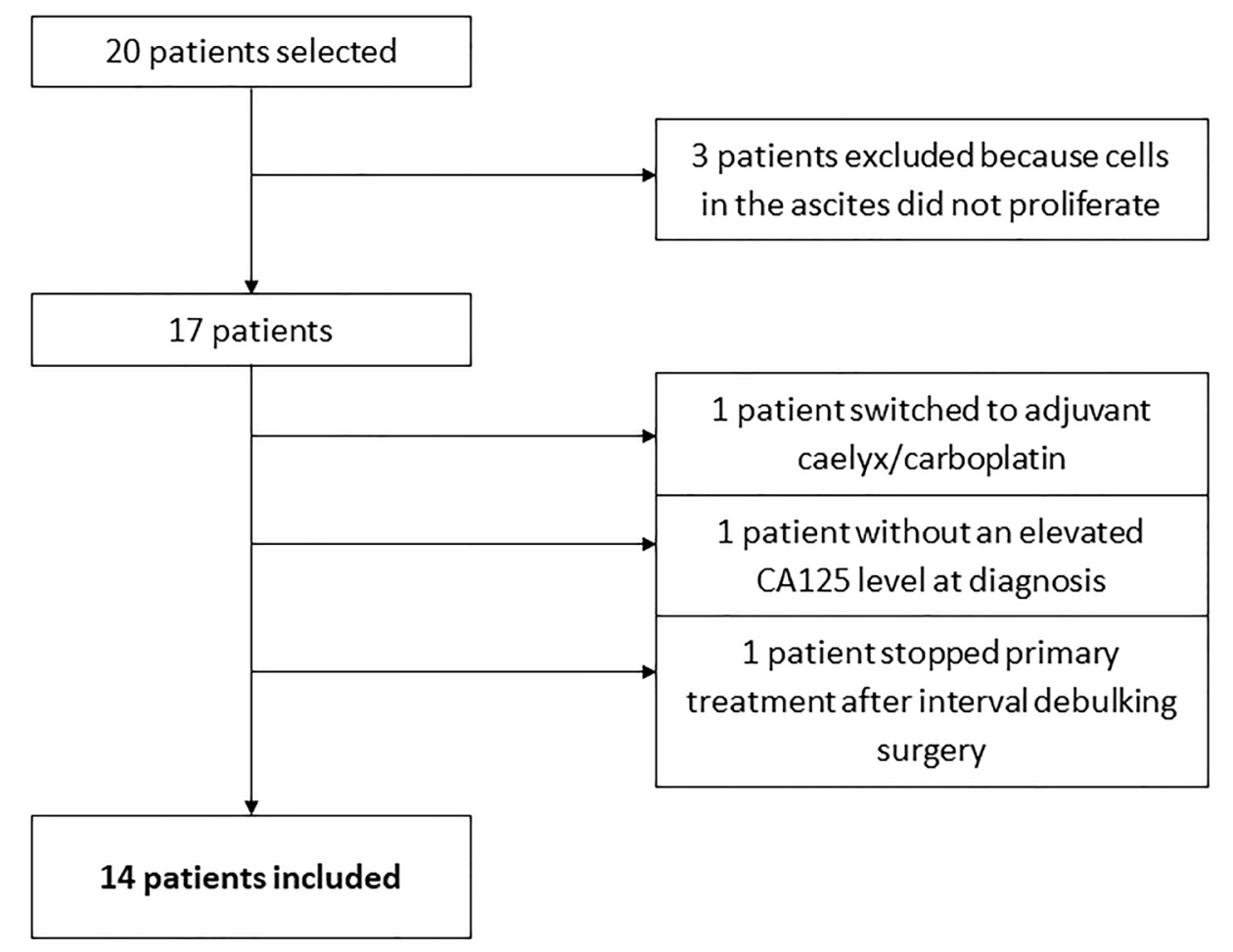

Figure 1: Flowchart of in- and exclusions.
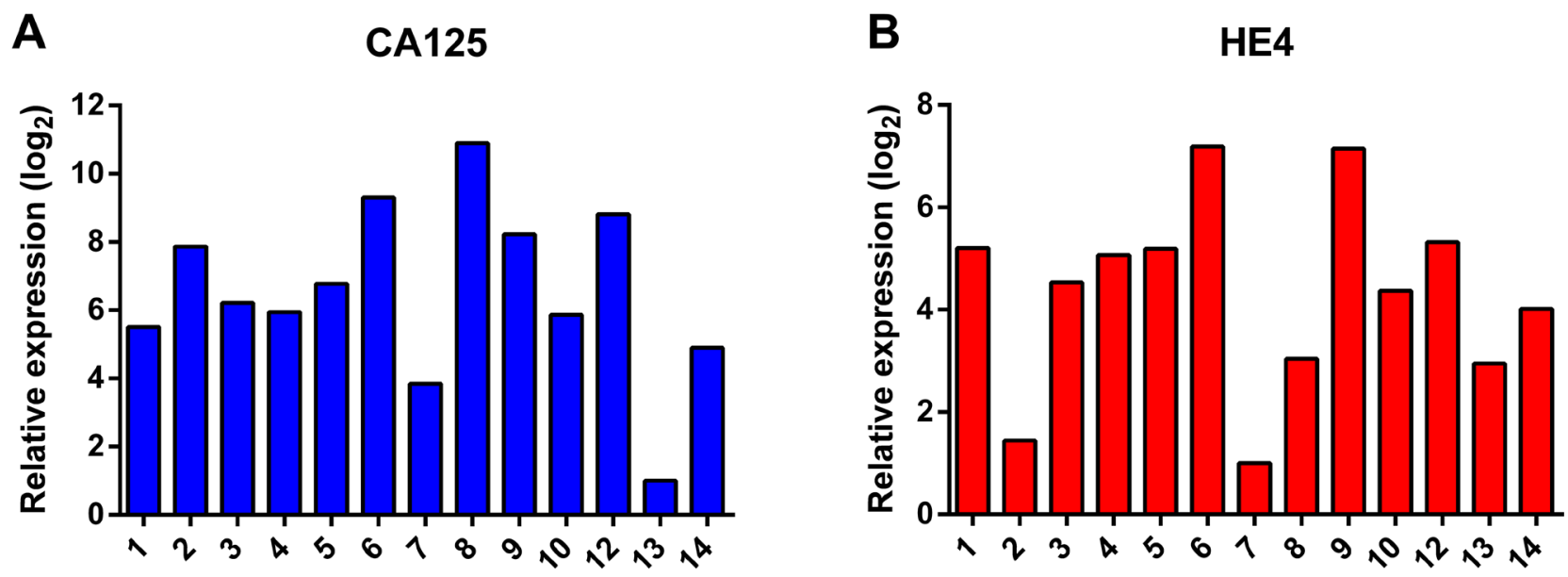

Figure 2: Analysis of the RNA expression of the ovarian cancer marker genes $C A 125$ (A) and HE4 (B). Expression levels were normalized to the expression of the housekeeping gene $\beta$-actin $(A C T B)$ and ribosomal protein $\mathrm{S} 18$ (RPS18). 
Table 2: Detailed characteristics of patients and results of in vitro drug sensitivity tests with tumor cells isolated from ascites

\begin{tabular}{|c|c|c|c|c|c|c|c|c|c|c|c|c|}
\hline \multicolumn{2}{|c|}{ Patient } & \multicolumn{3}{|c|}{ Clinical characteristics } & \multicolumn{5}{|c|}{ Clinical outcome } & \multicolumn{3}{|c|}{ In vitro outcome } \\
\hline Ps. & Age & $\begin{array}{l}\text { FIGO } \\
\text { stage }\end{array}$ & $\begin{array}{c}\text { Type of } \\
\text { chemotherapy }\end{array}$ & Surg. & $\begin{array}{c}\text { Outcome } \\
\text { surgery }\end{array}$ & $\begin{array}{c}\text { CA125 level at } \\
\text { diagnosis, } \\
\text { E/mL }\end{array}$ & $\begin{array}{c}\text { CA125 level } \\
\text { at end of } \\
\text { therapy, } \\
\text { E/mL }\end{array}$ & $\begin{array}{l}\text { Platinum } \\
\text { sensitivity }\end{array}$ & $\begin{array}{c}\text { BRCA } \\
\text { mutation on } \\
\text { tumor }\end{array}$ & $\begin{array}{c}\mathbf{G I}_{50} \\
\text { carbo, } \\
\mu \mathrm{mol} / \mathrm{L}\end{array}$ & $\begin{array}{c}\mathrm{GI}_{50} \\
\text { cisplatin, } \\
\mu \mathrm{mol} / \mathrm{L}\end{array}$ & $\begin{array}{c}\mathbf{G I}_{50} \\
\text { paclitaxel } \\
\mathrm{nmol} / \mathrm{L}\end{array}$ \\
\hline 1 & 71 & IIIc & $\operatorname{cis} / \operatorname{tax}^{a}$ & PDS & Optimal & 1154 & 10 & Resistant & unknown & & 2.1 & 12 \\
\hline 2 & 64 & IIIc & carbo/tax & IDS & Complete & 1800 & 34 & Resistant & $B R C A 1$ & 43.5 & & 35 \\
\hline 3 & 66 & IIIc & cis/carbo/ tax ${ }^{\mathrm{a}}$ & PDS & Optimal & 1242 & 5 & Resistant & $B R C A$ negative & 80.6 & 20.6 & 12 \\
\hline 4 & 64 & IIIc & carbo/tax & PDS & Optimal & 1481 & 15 & Sensitive & unknown & 77.9 & & 10 \\
\hline 5 & 64 & IIIc & carbo/tax & PDS & Optimal & 2400 & 26 & Sensitive & unknown & 90.7 & & 14 \\
\hline 6 & 55 & IIIc & $\operatorname{cis} / \operatorname{tax}^{\mathrm{a}}$ & PDS & Complete & 67 & 11 & Resistant & $B R C A$ negative & & 11.8 & 45 \\
\hline 7 & 68 & IIIc & carbo/tax & None & N/A & 3600 & 258 & Resistant & $B R C A$ negative & 100.0 & & 66 \\
\hline 8 & 58 & $\mathrm{IVb}$ & carbo/tax & IDS & Optimal & 121 & 15 & Resistant & $B R C A$ negative & 71.4 & & 3 \\
\hline 9 & 64 & $\mathrm{IVb}$ & carbo/tax & IDS & Complete & 1834 & 35 & Sensitive & $B R C A 2$ & 56.8 & & 42 \\
\hline 10 & 52 & IVa & carbo/tax & IDS & Complete & 1621 & 15 & Sensitive & $B R C A$ negative & 100.0 & & 35 \\
\hline 11 & 50 & IIIc & carbo/tax & IDS & Complete & 2500 & 16 & Sensitive & $B R C A 1$ & 84.0 & & 14 \\
\hline 12 & 54 & IIIc & carbo/tax & PDS & Optimal & 351 & 14 & Sensitive & $B R C A$ negative & 44.1 & & 24 \\
\hline 13 & 60 & IIIc & carbo/tax & PDS & Optimal & 500 & 8 & Sensitive & $B R C A$ negative & 100.0 & & 79 \\
\hline 14 & 51 & IVa & carbo/tax & IDS & Complete & 3900 & 9 & Sensitive & unknown & 31.4 & & 83 \\
\hline
\end{tabular}

${ }^{a}$ Received at least one cycle of intraperitoneal chemotherapy with cisplatin. Abbreviations: Age, age at time of diagnosis; carbo, carboplatin; cis, cisplatin; GI ${ }_{50}$, concentration of $50 \%$ cell growth inhibition; IDS, interval debulking surgery; PDS, primary debulking surgery; Ps., patient sample; Surg., surgery; tax, paclitaxel.

chemotherapy treatment of ps. 13 was delayed due to a fever of unknown origin. It is known that activation of the immune system can have a positive effect on tumor regression in ovarian cancer [19-21]. Although speculative, this may also have been the case in this patient.

CA125 level as a measure for clinical outcome can be debated. CA125 is elevated in, on average, $80 \%$ of EOC patients at time of diagnosis [22]. In our study, one patient did not have elevated CA125 at diagnosis. Therefore, it was not possible to determine clinical outcome and the patient was excluded. Furthermore, only one patient (ps. 7) showed poor clinical outcome with a CA125 above 35 $\mathrm{E} / \mathrm{ml}$ after primary treatment. However, this is in line with clinical practice where $80-85 \%$ of patients respond to primary chemotherapy treatment [5]. Another possibility to measure clinical outcome is to include disease-free or overall survival of patients in the assessment. However, these data were not available for all patients at the time of evaluation of clinical response. Moreover, by using disease-free survival as clinical criterium, other aspects of treatment, such as the outcome of the debulking surgery, also play a role. We evaluated platinum sensitivity as a measure of clinical outcome, but this did not show correlation with CA125 level after primary treatment. However, the definition of platinum resistance is arbitrary, and can be influenced by the timing and modality of follow-up, independent of tumor biology [23]. Since we were mainly interested in the primary response of the ovarian tumors on chemotherapy, we chose CA125 level. This points out the difficulty of determining an appropriate measure for clinical outcome. Therefore, in an expansion of this study, different variables to measure the response to chemotherapy will be taken into account, including CA125 level, outcome of CT-scan using RECIST-criteria $[24,25]$, outcome of the debulking surgery, and the histopathologic chemotherapy response score [22]. These 
Table 3: Quantification of cell surface expression of CA125 and EpCAM, and intracellular expression of $\mathrm{CK} 7$ in ascites cell samples by determination of the ratio of the median fluorescence intensity (MFI) after staining with anti-CA125, anti-EpCAM or anti-CK7 antibody relative to staining with isotype control antibody

\begin{tabular}{lcccccc}
\hline \multirow{2}{*}{$\begin{array}{l}\text { Patient } \\
\text { sample }\end{array}$} & \multicolumn{2}{c}{ CA125 } & \multicolumn{2}{c}{ EpCAM } & \multicolumn{2}{c}{ CK7 } \\
\cline { 2 - 7 } & MFI ratio & \% positive & MFI ratio & \% positive & MFI ratio & \% positive \\
\hline 1 & 1.35 & 47 & 0.93 & 3.4 & 10.9 & 80 \\
2 & 1.26 & 42 & 0.96 & 1.6 & 9.65 & 89 \\
4 & 1.30 & 47 & 0.98 & 3.3 & 9.59 & 85 \\
12 & 3.01 & 90 & 1.41 & 23 & 15.5 & 93 \\
14 & 2.48 & 87 & 1.28 & 22 & 6.69 & 87 \\
SK-OV-3 & 1.85 & 47 & 339 & 99 & 1.50 & 36 \\
\hline
\end{tabular}

Moreover, the percentage of cells stained positive for the different markers was determined. Abbreviations: MFI, median fluorescence intensity.

variables, together with platinum sensitivity, PFS, and OS will further substantiate the conclusion for clinical outcome.

We used strict inclusion criteria to have a homogenous group of ovarian cancer patients. Therefore, patients with tumors with a histology other than high-grade serous were excluded. However, women with mucinous tumors are described as poor responders to chemotherapy, and having poor prognosis [26]. Adding patients with, for instance, this histology type would broaden the clinical applicability of the in vitro drug sensitivity tests.

Besides the proliferation assays, the addition of gene mutation analysis of $B R C A$ could add more value in predicting chemotherapy response. $B R C A$ mutations in the tumor have been linked to improved survival [7]. For three of the ten patients tested for somatic $B R C A$ mutation, a $B R C A 1$ or $B R C A 2$ mutation was identified. Another marker predicting chemotherapy response is the immune checkpoint programmed death-ligand 1 (PD-L1). High expression of PD-L1 has been linked to poor prognosis [27], although opposite results have been reported as well [28]. In an expansion of the current study, the relationship between $B R C A$ mutations, and PD-L1 expression on ascites tumor cells and clinical outcome will be investigated.

In conclusion, our study shows the feasibility of assessing in vitro chemotherapy sensitivity on tumor cells isolated from ascites. A larger, prospective study, which takes into account the insights that were gained in this pilot study, is ongoing and will be reported in due course.

\section{MATERIALS AND METHODS}

\section{Patients}

Ascites samples of advanced stage EOC patients were used. The samples were selected from both the Gynecologic Oncology Biobank of the Radboud university medical center and the prospective ASCITES study (since 2018). Ascites was obtained during primary debulking surgery, or during paracentesis for diagnostics or symptom relieve with the aim to use the ascites for research. Three hospitals participate in the ASCITES study: Radboud university medical center, Canisius Wilhelmina Hospital in Nijmegen, and Catharina Hospital in Eindhoven (The Netherlands). The following eligibility criteria were applied: women of eighteen years or older, who were diagnosed with advanced stage highgrade serous ovarian cancer, had a sufficient amount of ascites to collect, which contained enough vital cells, were chemotherapy naive, and signed informed consent. Patients with a history of cancer except basal cell carcinoma, with concurrent malignant disease, or who did not finish primary treatment were excluded. The following data of patients were collected from the electronic patient files and anonymously stored in a database: age, performance status, histology of tumor, CA125 level, BRCA mutant status of the tumor, order and type of (chemotherapy) treatment, and follow-up data six months after finishing primary treatment. The study was conducted with approval of the Medical Ethical Review Board of Nijmegen and Arnhem and the local medical ethical committees of Canisius Wilhelmina and Catharina Hospital (no. 2015-2060 and 2018-4528).

\section{Clinical response}

To define clinical response to therapy, the status of remission was determined, using the level of CA125 in serum. The reference range in clinical practice is $0-35$ $\mathrm{E} / \mathrm{mL}$. Of the patients with an elevated CA125 level at time of diagnosis, a serum CA125 level of $35 \mathrm{E} / \mathrm{mL}$ or higher after primary treatment was defined as a 'poor' clinical outcome. Clinical outcome was defined as 'good' when CA125 was equal or below $35 \mathrm{E} / \mathrm{mL}$. Platinum resistance was defined as the progression during, or recurrence within six months after finishing primary 
treatment. Patients were labelled platinum sensitive if no signs of recurrent disease occurred within six months after finishing primary treatment.

\section{Mutation status}

The mutation status of the $B R C A 1$ and $B R C A 2$ genes in the tumors was determined by DNA sequencing. $B R C A$ genetic analysis is performed in all newly diagnosed and recurrent cases of EOC in the Netherlands since 2016. Data on the $B R C A$ gene mutation status are lacking for several cases before 2016 .

\section{Tumor cell enrichment and culture}

The ascites was filtered, cells were collected by centrifugation and then frozen as described by Wefers et al. [29]. Ascites cell samples were enriched for tumor cells by seeding in tissue culture flasks and allowing to adhere overnight. The next day, non-adherent cells were removed and confirmed to contain primarily immune cells by flow cytometry. The adherent cells were cultured for two to three weeks. Cell culture medium was advanced RPMI (Thermo Fisher), supplemented with 10\% fetal bovine serum, $1 \%$ glutamax and $1 \%$ penicillin/streptomycin.
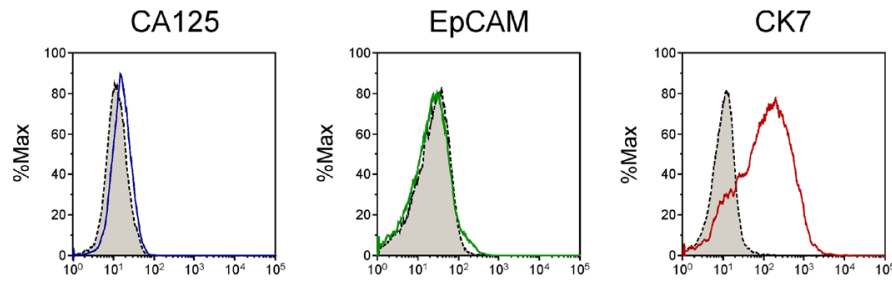

Ps. 1

$\mathrm{P}+3$
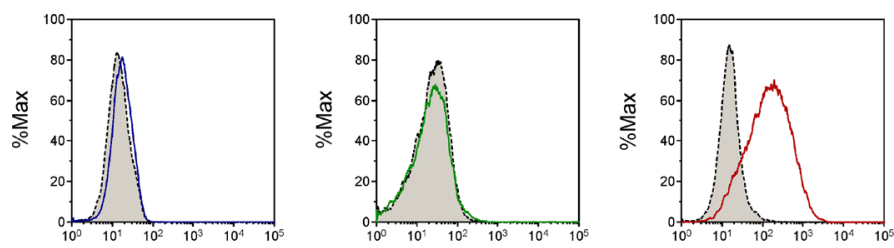

Ps. 2

$\mathrm{P}+3$
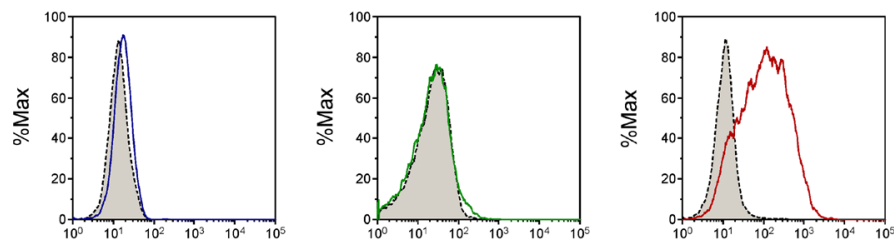

Ps. 4

$\mathrm{P}+3$
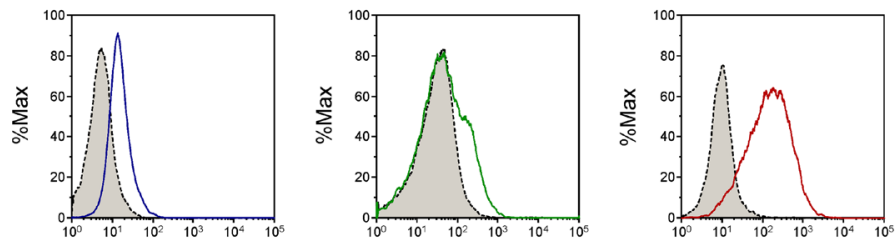

Ps. 12

$\mathrm{P}+3$
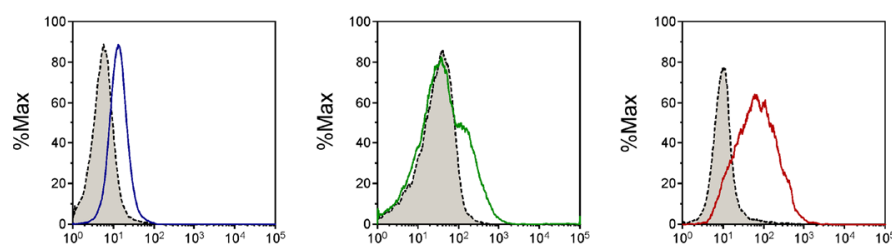

Ps. 14

$\mathrm{P}+2$
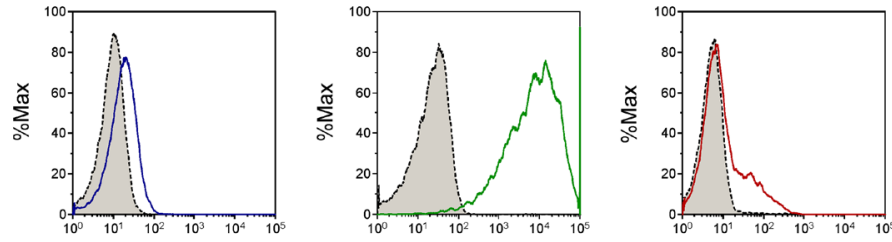

SK-OV-3

Figure 3: Analysis of tumor cell markers CA125, EpCAM and CK7 on primary patient-derived cell cultures by flow cytometry using fluorescently labeled antibodies. Grey-shaded peaks represent the staining with isotype control antibodies. Passage number $(\mathrm{P})$ from collection of cells from ascites is indicated. The adenocarcinoma ovarian cancer cell line SK-OV-3 was analyzed for reference. Expression was quantified by determination of shift in fluorescence peaks (Table 3). 
Bright field images were captured with a Nikon D3200 camera on an Axiovert 25 CFL light microscope (Zeiss). Brightness and contrast filters were applied on the images. Cells were collected by trypsinization to characterize in gene expression analysis (qPCR), flow cytometry, and proliferation assays.

\section{Gene expression analysis}

RNA was isolated with RNeasy (Qiagen, Venlo, the Netherlands). cDNA was prepared using QuantiTect Reverse Transcription kit (Qiagen). qPCR was performed in a Bio-Rad CFX96 cycler using SYBR ${ }^{\text {TM }}$ Select Master Mix (Thermo Fisher). The thermal cycle protocol used was as follows: $50^{\circ} \mathrm{C}$ for $10 \mathrm{~min}, 5 \mathrm{~min}$ initial denaturation at $95^{\circ} \mathrm{C}$, and 40 cycles of 10 seconds denaturation at $94^{\circ} \mathrm{C}$, 20 seconds annealing at $60^{\circ} \mathrm{C}$, and 30 seconds extension at $72^{\circ} \mathrm{C}$. A dissociation curve was added at the end of the cycle. PCR data were analyzed using the $2^{-\Delta \Delta \mathrm{CT}}$ method [30] and both the $\beta$-actin $(A C T B)$ and ribosomal protein S18 (RPS18) genes were used as housekeeping controls. The primers for the qPCR were designed in-house and synthesized at Thermo Fisher. Primers were: HE4 forward: CAAGAGTGCGTCTCGGACAG; HE4 reverse: TTAATGTTCACCTGGGGGCA; CA125 forward: CA CAGACAACGTCATGCAGC; CA125 reverse: TGGG AGTTGTAGGAGGCTCA; $\beta$-actin forward: CAAGA GATGGCCACGGCTGCTTCCA; $\beta$-actin reverse: ATGGAGTTGAAGGTAGTTTCG; ribosomal protein S18 forward: CGATGGGCGGCGGAAAAT; ribosomal protein S18 reverse: CGTTCCACCTCATCCTCAGTG.

\section{Flow cytometry}

For surface staining, cells were harvested and washed in $0.5 \%(\mathrm{w} / \mathrm{v})$ bovine serum albumin $(\mathrm{BSA})$ in
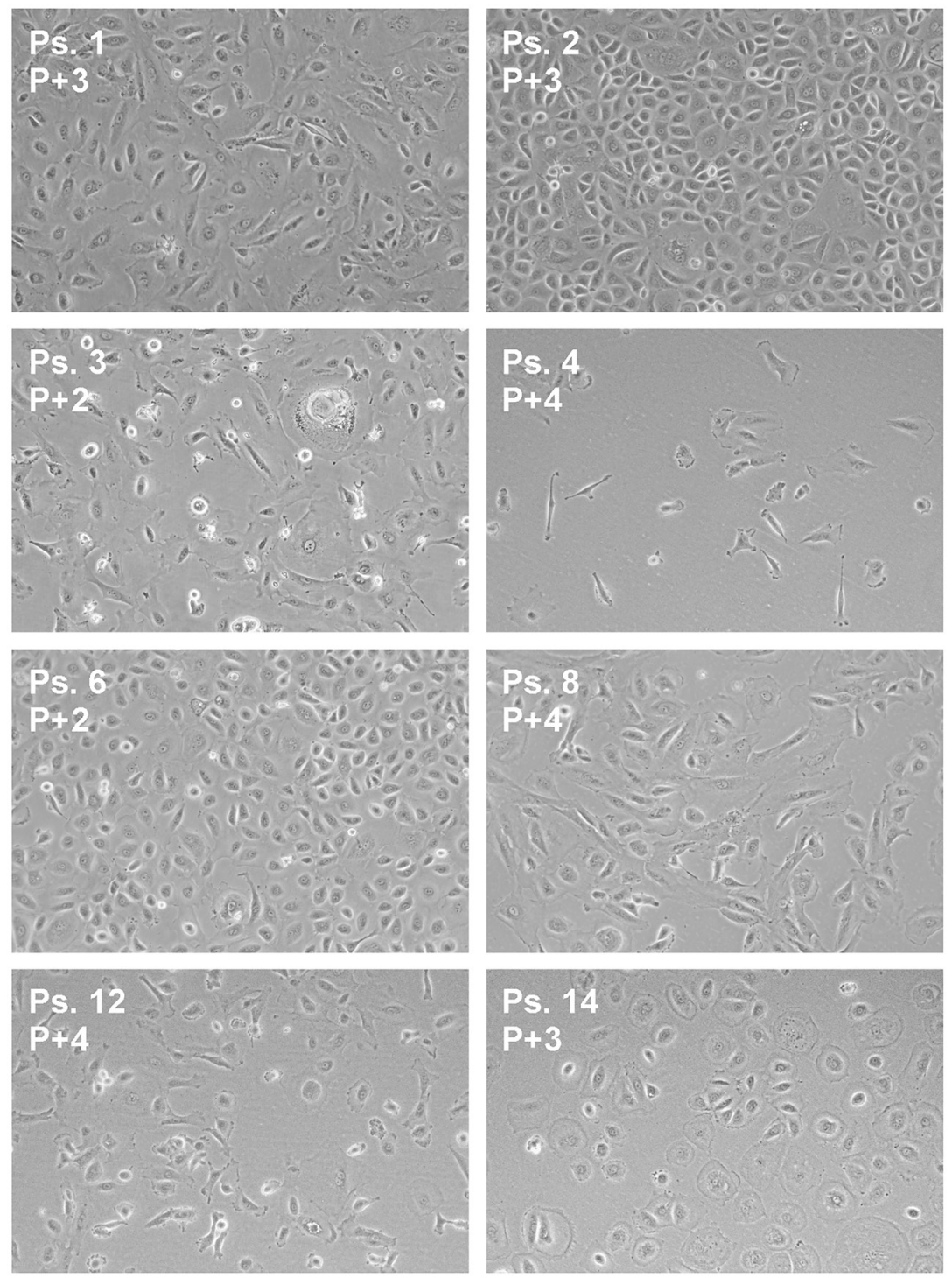

Figure 4: Morphology of ascites-derived adherent cells. Bright field images were captured at indicated passage number (P) at a magnification of $10 \times$. 
phosphate-buffered saline (PBS), before incubation with labeled antibodies for $30 \mathrm{~min}$. After washing twice with BSA in PBS, 7-aminoactinomycin (Miltenyi Biotec) was added and fluorescence was measured on a Guava easyCyte 12-HT flow cytometer (Luminex). For intracellular staining, cells were fixed in $4 \%$ paraformaldehyde for $10 \mathrm{~min}$ at $37^{\circ} \mathrm{C}$ and subsequently permeabilized with $0.1 \% \mathrm{PBS} /$ Triton $\mathrm{X}-100$ for $15 \mathrm{~min}$ at room temperature. After incubation with $10 \%$ normal goat serum (Sigma-Aldrich) for $30 \mathrm{~min}$ and FcR blocking reagent for $5 \mathrm{~min}$ to block aspecific binding, cells were incubated with primary antibody for $30 \mathrm{~min}$, washed with PBS and incubated with secondary antibody for $30 \mathrm{~min}$. After another wash, fluorescence was measured. Flow cytometry data were analyzed and histograms were made with Kaluza Analysis 2.1 software (Beckman Coulter).

carboplatin Ps. 7

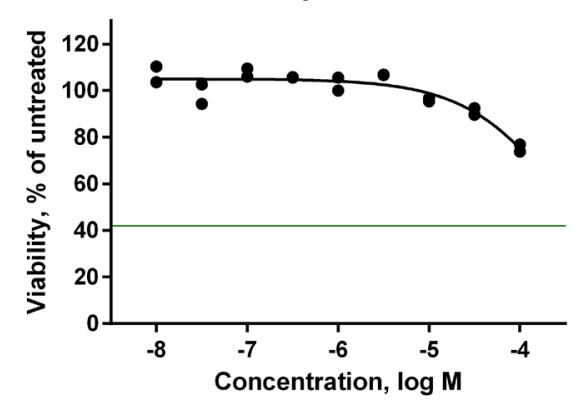

carboplatin Ps. 12

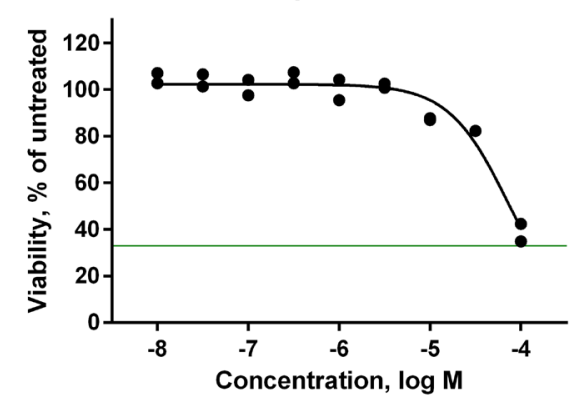

carboplatin Ps. 13

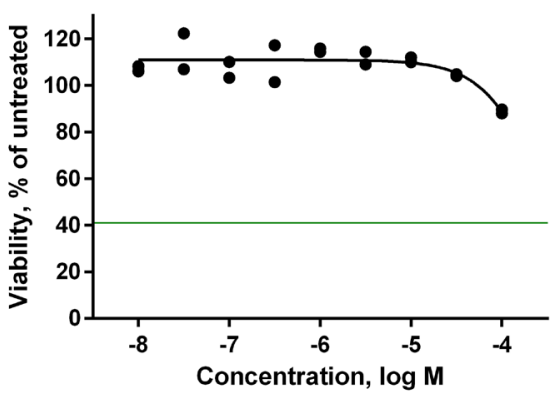

Cells with negative fluorescence intensities caused by fluorescence compensation were excluded from visual representation, but were included in the quantification of the data. The percentage of cells stained positive for the different markers was determined using the Enhanced Normalized Subtraction method [31]. To ensure tumor cells were studied, and to measure the expression of immune markers, antibodies for the following markers were used: CD45, immune cells (Miltenyi); CA125, ovarian cancer cells (AssayPro); EpCAM (CD326), epithelial cells (Miltenyi); FSP-1, Fibroblast antibody, fibroblasts and epithelial cells (Miltenyi); CK7, epithelial cells (Abcam). The immortalized ovarian cancer cell line SK-OV-3 was used as a control. The cell line was obtained from the American Type Culture Collection (Manassas, VA, USA.).
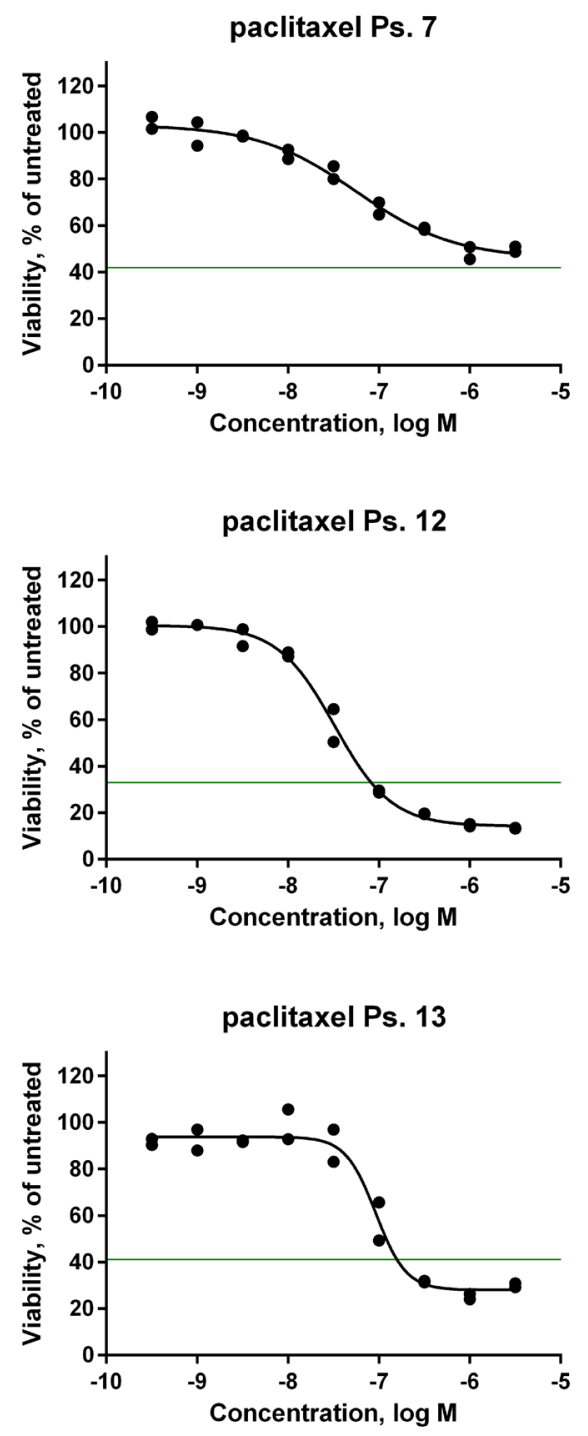

Figure 5: In vitro drug sensitivity analysis of primary patient-derived tumor cells. Dose-response curves of the first-line chemotherapeutic agents carboplatin and paclitaxel on tumor cells isolated from ascites of three patients. Cells were seeded in microtiter plates and allowed to adapt for 24 hours before drug was added. Effect on cell growth was determined after 120 hours drug exposure by measuring intracellular ATP content as an indirect readout of cell number. The horizontal green line corresponds to the number of cells before addition of drug. 


\section{Proliferation assays}

In vitro drug sensitivity was determined in cell proliferation assays after five days incubation with drug. Cells were counted and seeded in 384-well plates for proliferation assays as described [32]. The cell number was optimized to maximize the assay window and to ascertain that growth was not limited by cell density. Carboplatin (MedKoo), cisplatin and paclitaxel (Sigma Aldrich) were stored as dry powders at $4^{\circ} \mathrm{C}$. Carboplatin and cisplatin were freshly dissolved in $\mathrm{ddH}_{2} \mathrm{O}$ at the day of the assay. Paclitaxel was dissolved in dimethylsulfoxide (DMSO). Compound effects were measured in a 9-point dilution series in duplicate. As readout in the proliferation assays, intracellular ATP content was determined as an indirect measure of cell number, using ATPlite 1 Step solution (Perkin Elmer, Groningen, The Netherlands). Paclitaxel was tested in a range of $0.32 \mathrm{nmol} / \mathrm{L}$ to $3160 \mathrm{nmol} / \mathrm{L}$ for all samples. Carboplatin and cisplatin were tested in three ranges: $100 \mathrm{nmol} / \mathrm{L}$ to $100 \mu \mathrm{mol} / \mathrm{L}, 316 \mathrm{nmol} / \mathrm{L}$ to $316 \mu \mathrm{mol} / \mathrm{L}$, or $1 \mu \mathrm{mol} / \mathrm{L}$ to $1 \mathrm{mmol} / \mathrm{L}$. The same ranges for both compounds were used for the same samples. Exposure time was 120 hours for all compounds. To determine the potential synergistic effects of carboplatin and paclitaxel in vitro, 9-point dilution series of one of the two compounds were determined in the presence of the highest inactive concentration of the other compound.

\section{Dose-response curves}

The percentage growth of cells from the ascites fluid was calculated, and the effect of carboplatin, cisplatin, and paclitaxel on cell growth was calculated relative to control wells containing only vehicle. Dose-response curves were fitted by non-linear regression using XLfit5. Maximal and minimal signals were locked, where appropriate, to obtain the best fit as indicated by the $F$-test as implemented in XLfit5. Effect on cell growth was quantified by calculation of the $\mathrm{GI}_{50}$, which is the concentration at which the anti-cancer agents inhibited cell growth with $50 \%$ in comparison to cells treated with only the vehicle. $\mathrm{GI}_{50}$ accounts for starting cell density and differences in proliferation rates between the tumor cell samples [32].

\section{Statistics}

Baseline characteristics were summarized using descriptive statistics. Association between in vitro sensitivity tests and clinical outcome were analyzed by Pearson correlation. Normal distribution was confirmed with the Shapiro-Wilk test. For comparison of the clinical outcome and in vitro response measurements in ascites binary variables were defined. A cut-off measure for $\mathrm{GI}_{50}$ of all compounds $(N=14)$ was determined using the median, for poor or good in vitro outcome. Comparisons of clinical outcome, BRCA mutations, and the in vitro response measurements were assessed with two-sided $T$-test, and the Fisher's Exact test. Finally, the response to the combination of compounds as it is clinically used was determined. An in vitro outcome was considered good if the response to one of the compounds was good, and poor if the in vitro tests with both compounds resulted in a high $\mathrm{GI}_{50}$. Statistical analyses were performed using IBM SPSS Statistics version 25 .

\section{Abbreviations}

CA125: cancer antigen 125; CK7: cytokeratin 7; CT: computer tomography; EOC: epithelial ovarian cancer; EpCAM: epithelial adhesion molecule; FIGO: International Federation of Gynecology and Obstetrics; MFI: median fluorescence intensity; IV: intravenous; IP: intraperitoneal; PARP-inhibitor: Poly (ADP ribose) polymerase 1 inhibitor; PFS: progression free survival; OS: overall survival; PD-L1: programmed death-ligand 1; ps: patient sample.

\section{Author contributions}

Concept and design: G.J.R. Zaman, A.M. van Altena; Development of methodology: G.J.R. Zaman, J. Dylus, A.M. van Doornmalen, W.R. Mulder; Acquisition of data: J.E. den Ouden; Performed the experiments: J. Dylus, A.M. van Doornmalen, W.R. Mulder, W.E. van Riel; Analysis and interpretation of data: J.E. den Ouden, G.J.R. Zaman, J. Dylus, A.M. van Doornmalen, W.R. Mulder, Y. Grobben, W.E. van Riel, A.M. van Altena; Acquisition of funding: G.J.R. Zaman, R.C. Buijsman, A.M. van Altena; Writing of the manuscript: J.E. den Ouden, G.J.R. Zaman, Y. Grobben, W.E. van Riel, J.A. de Hullu, A.M. van Altena.

\section{ACKNOWLEDGMENTS}

The authors thank Jolien van der Meer and Ralph Maas for processing the ascites for storage, Jeffrey Kooijman for analysis of data and Dr. Joost Uitdehaag for critical reading of the manuscript.

\section{CONFLICTS OF INTEREST}

J.E. den Ouden partly received salary support from Netherlands Translational Research Center B.V. G.J.R. Zaman and R.C. Buijsman are shareholders and managing director of Netherlands Translational Research Center B.V.

\section{FUNDING}

Grant of 'Stichting Ruby and Rose' to A.M. van Altena. 


\section{REFERENCES}

1. American Cancer Society. Cancer Facts \& Figures 2019. Atlanta: American Cancer Society. 2019.

2. Timmermans M, Sonke GS, Van de Vijver KK, van der Aa MA, Kruitwagen R. No improvement in long-term survival for epithelial ovarian cancer patients: A population-based study between 1989 and 2014 in the Netherlands. Eur J Cancer. 2018; 88:31-7. https://doi.org/10.1016/j.ejca.2017.10.030. [PubMed]

3. Arend R, Martinez A, Szul T, Birrer MJ. Biomarkers in ovarian cancer: To be or not to be. Cancer. 2019 (Suppl 24); 125:4563-72. https://doi.org/10.1002/cncr.32595. [PubMed]

4. Dutch Guideline on Epithelial Ovarian Cancer. Oncoline. 2020. https://www.oncoline.nl/ovariumcarcinoom.

5. Cannistra SA. Cancer of the ovary. N Engl J Med. 2004; 351:2519-29. https://doi.org/10.1056/NEJMra041842. [PubMed]

6. Lloyd KL, Cree IA, Savage RS. Prediction of resistance to chemotherapy in ovarian cancer: a systematic review. BMC Cancer. 2015; 15:117. https://doi.org/10.1186/s12885-0151101-8. [PubMed]

7. Pennington KP, Walsh T, Harrell MI, Lee MK, Pennil CC, Rendi MH, Thornton A, Norquist BM, Casadei S, Nord AS, Agnew KJ, Pritchard CC, Scroggins S, et al. Germline and somatic mutations in homologous recombination genes predict platinum response and survival in ovarian, fallopian tube, and peritoneal carcinomas. Clin Cancer Res. 2014; 20:764-75. https://doi.org/10.1158/1078-0432.Ccr-13-2287. [PubMed]

8. Tomao F, Bardhi E, Di Pinto A, Sassu CM, Biagioli E, Petrella MC, Palaia I, Muzii L, Colombo N, Panici PB. Parp inhibitors as maintenance treatment in platinum sensitive recurrent ovarian cancer: An updated meta-analysis of randomized clinical trials according to BRCA mutational status. Cancer Treat Rev. 2019; 80:101909. https://doi. org/10.1016/j.ctrv.2019.101909. [PubMed]

9. Konstantinopoulos PA, Ceccaldi R, Shapiro GI, D'Andrea AD. Homologous Recombination Deficiency: Exploiting the Fundamental Vulnerability of Ovarian Cancer. Cancer Discov. 2015; 5:1137-54. https://doi.org/10.1158/21598290.Cd-15-0714. [PubMed]

10. Weren RD, Mensenkamp AR, Simons M, Eijkelenboom A, Sie AS, Ouchene H, van Asseldonk M, Gomez-Garcia EB, Blok MJ, de Hullu JA, Nelen MR, Hoischen A, Bulten J, et al. Novel BRCA1 and BRCA2 Tumor Test as Basis for Treatment Decisions and Referral for Genetic Counselling of Patients with Ovarian Carcinomas. Hum Mutat. 2017; 38:226-35. https://doi.org/10.1002/humu.23137. [PubMed]

11. Huang H, Li YJ, Lan CY, Huang QD, Feng YL, Huang YW, Liu JH. Clinical significance of ascites in epithelial ovarian cancer. Neoplasma. 2013; 60:546-52. https://doi. org/10.4149/neo_2013 071. [PubMed]

12. Konecny G, Crohns C, Pegram M, Felber M, Lude S, Kurbacher C, Cree IA, Hepp H, Untch M. Correlation of drug response with the ATP tumorchemosensitivity assay in primary FIGO stage III ovarian cancer. Gynecol Oncol. 2000; 77:258-63. https://doi.org/10.1006/gyno.2000.5728. [PubMed]

13. Kerr EH, Frederick PJ, Egger ME, Stockard CR, Sellers J, DellaManna D, Oelschlager DK, Amm HM, Eltoum IE, Straughn JM, Buchsbaum DJ, Grizzle WE, McNally LR. Lung resistance-related protein (LRP) expression in malignant ascitic cells as a prognostic marker for advanced ovarian serous carcinoma. Ann Surg Oncol. 2013; 20:305965. https://doi.org/10.1245/s10434-013-2878-9. [PubMed]

14. Lane D, Matte I, Garde-Granger P, Laplante C, Carignan A, Rancourt C, Piche A. Inflammation-regulating factors in ascites as predictive biomarkers of drug resistance and progression-free survival in serous epithelial ovarian cancers. BMC Cancer. 2015; 15:492. https://doi. org/10.1186/s12885-015-1511-7. [PubMed]

15. Chen YL, Cheng WF, Chang MC, Lin HW, Huang CT, Chien CL, Chen CA. Interferon-gamma in ascites could be a predictive biomarker of outcome in ovarian carcinoma. Gynecol Oncol. 2013; 131:63-8. https://doi.org/10.1016/j. ygyno.2013.07.105. [PubMed]

16. Latifi A, Luwor RB, Bilandzic M, Nazaretian S, Stenvers K, Pyman J, Zhu H, Thompson EW, Quinn MA, Findlay JK, Ahmed N. Isolation and characterization of tumor cells from the ascites of ovarian cancer patients: Molecular phenotype of chemoresistant ovarian tumors. PLoS ONE. 2012; 7:e46858. https://doi.org/10.1371/journal.pone.0046858. [PubMed]

17. Kipps E, Tan DSP, Kaye, SB. Meeting the challenge of ascites in ovarian cancer: new avenues for therapy and research. Nat Rev Cancer. 2013; 13:273-82. https://doi. org/10.1038/nrc3432. [PubMed]

18. Hill SJ, Decker B, Roberts EA, Horowitz NS, Muto MG, Worley MJ Jr, Feltmate CM, Nucci MR, Swisher EM, Nguyen H, Yang C, Morizane R, Kochupurakkal BS, et al. Prediction of DNA Repair Inhibitor Response in Short-Term Patient-Derived Ovarian Cancer Organoids. Cancer Discov. 2018; 8:1404-21. https://doi.org/10.1158/2159-8290.Cd-180474. [PubMed]

19. Roelofsen T, Wefers C, Gorris MAJ, Textor JC, Massuger L, de Vries IJM, van Altena AM. Spontaneous Regression of Ovarian Carcinoma After Septic Peritonitis; A Unique Case Report. Front Oncol. 2018; 8:562. https://doi.org/10.3389/ fonc.2018.00562. [PubMed]

20. Felgner S, Kocijancic D, Frahm M, Weiss S. Bacteria in Cancer Therapy: Renaissance of an Old Concept. Int J Microbiol. 2016; 2016:8451728. https://doi. org/10.1155/2016/8451728. [PubMed]

21. Turner TB, Buchsbaum DJ, Straughn JM Jr, Randall TD, Arend RC. Ovarian cancer and the immune system - The role of targeted therapies. Gynecol Oncol. 2016; 142:34956. https://doi.org/10.1016/j.ygyno.2016.05.007. [PubMed]

22. Cohen PA, Powell A, Böhm S, Gilks CB, Stewart CJ, Meniawy TM, Bulsara M, Avril S, Brockbank EC, Bosse T, de Azevedo Focchi GR, Ganesan R, Glasspool RM, et al, and HGSC CRS Collaborative Network (Supplementary 1). 
Pathological chemotherapy response score is prognostic in tubo-ovarian high-grade serous carcinoma: A systematic review and meta-analysis of individual patient data. Gynecol Oncol. 2019; 154:441-448. https://doi. org/10.1016/i.ygyno.2019.04.679. [PubMed]

23. Lindemann K, Gao B, Mapagu C, Fereday S, Emmanuel C, Alsop K, Traficante N, Harnett PR, Bowtell DD, deFazio A, and Australian Ovarian Cancer Study Group. Response rates to second-line platinum-based therapy in ovarian cancer patients challenge the clinical definition of platinum resistance. Gynecol Oncol. 2018; 150:239-46. https://doi. org/10.1016/i.ygyno.2018.05.020. [PubMed]

24. Eisenhauer EA, Therasse P, Bogaerts J, Schwartz LH, Sargent D, Ford R, Dancey J, Arbuck S, Gwyther S, Mooney M, Rubinstein L, Shankar L, Dodd L, et al. New response evaluation criteria in solid tumours: revised RECIST guideline (version 1.1). Eur J Cancer. 2009; 45:228-47. https://doi.org/10.1016/j.ejca.2008.10.026. [PubMed]

25. Rustin GJ, Vergote I, Eisenhauer E, Pujade-Lauraine E, Quinn M, Thigpen T, du Bois A, Kristensen G, Jakobsen A, Sagae S, Greven K, Parmar M, Friedlander M, et al. Definitions for response and progression in ovarian cancer clinical trials incorporating RECIST 1.1 and CA 125 agreed by the Gynecological Cancer Intergroup (GCIG). Int $\mathrm{J}$ Gynecol Cancer. 2011; 21:419-23. https://ijgc.bmj.com/ content $/ 21 / 2 / 419$. [PubMed]

26. du Bois A, Reuss A, Pujade-Lauraine E, Harter P, RayCoquard I, Pfisterer J. Role of surgical outcome as prognostic factor in advanced epithelial ovarian cancer: a combined exploratory analysis of 3 prospectively randomized phase 3 multicenter trials: by the Arbeitsgemeinschaft Gynaekologische Onkologie Studiengruppe Ovarialkarzinom (AGO-OVAR) and the Groupe d'Investigateurs Nationaux Pour les Etudes des Cancers de l'Ovaire (GINECO). Cancer. 2009; 115:1234 44. https://doi.org/10.1002/cncr.24149. [PubMed]
27. Hamanishi J, Mandai M, Iwasaki M, Okazaki T, Tanaka Y, Yamaguchi K, Higuchi T, Yagi H, Takakura K, Minato N, Honjo T, Fujii S. Programmed cell death 1 ligand 1 and tumor-infiltrating CD8+ $\mathrm{T}$ lymphocytes are prognostic factors of human ovarian cancer. Proc Natl Acad Sci U S A. 2007; 104:3360-5. https://doi.org/10.1073/ pnas.0611533104. [PubMed]

28. Webb JR, Milne K, Kroeger DR, Nelson BH. PD-L1 expression is associated with tumor-infiltrating $\mathrm{T}$ cells and favorable prognosis in high-grade serous ovarian cancer. Gynecol Oncol. 2016; 141:293-302. https://doi. org/10.1016/i.ygyno.2016.03.008. [PubMed]

29. Wefers C, Bakdash G, Moreno Martin M, Duivemande Boer T, Torensma R, Massuger LF, de Vries IJ. Isolation of Mononuclear Cell Populations from Ovarian Carcinoma Ascites. Bio Protoc. 2017; 7:e2219. https://doi. org/10.21769/BioProtoc.2219.

30. Livak KJ, Schmittgen TD. Analysis of relative gene expression data using real-time quantitative PCR and the $2^{-\triangle \Delta C T}$ method. Methods. 2001; 25:402-408. https://doi. org/10.1006/meth.2001.1262. [PubMed]

31. Bagwell G. A journey through flow cytometric immunofluorescence analyses - Finding accurate and robust algorithms that estimate positive fraction distributions. Clin Immunol Newsl. 1996; 16:33-7. https://doi.org/10.1016/ S0197-1859(00)80002-3.

32. Uitdehaag JC, de Roos JA, Prinsen MB, WillemsenSeegers N, de Vetter JR, Dylus J, van Doornmalen AM, Kooijman J, Sawa M, van Gerwen SJ, de Man J, Buijsman RC, Zaman GJ. Cell panel profiling reveals conserved therapeutic clusters and differentiates the mechanism of action of different PI3K/mTOR, Aurora kinase and EZH2 inhibitors. Mol Cancer Ther. 2016; 15:3097-3109. https:// doi.org/10.1158/1535-7163.MCT-16-0403. [ubMed] 